\title{
Analyzing the Intention to Purchase Proton Automobiles: Preliminary Findings
}

\author{
Uchenna Cyril Eze \\ BNU-HKBU United International College \\ E-Mail: uc_chinwe@hotmail.com \\ Kwan Pay Yee \\ Multimedia University \\ E-Mail: py.kwan81 @hotmatil.com \\ Fenella Wamala \\ Multimedia University \\ E-Mail: wanella18@yahoo.com
}

\begin{abstract}
The automobile industry in Malaysia is growing, and the local car manufacturers are investing heavily in research and development to enable products that are more functional. This is in the bid to compete with the growing popularity of foreign cars in Malaysia. This industry is expected to grow steadily in the near future due to the high demand for premium products, and as the working population and families in Malaysia become more affluent. The main objective of this research, therefore, is to examine the influence of key factors including country of origin, advertising, brand image, product knowledge, product quality, and price on consumers' purchase intention for Proton vehicles in Malaysia. We used a survey questionnaire to collect 988 valid responses from participants selected from four cities using convenient sampling method. Data collected were analyzed using Pearson correlation and multiple linear regression. The findings reveal that all the hypotheses were supported except for brand image and product quality. Finally, we outlined specific research and practice contributions based on the findings, and highlighted areas for future research.
\end{abstract}

Keywords: Product Quality, Image, Knowledge, Advertising, Consumers' Purchase Decision, Automobile, Malaysia 


\section{INTRODUCTION}

An automobile, simply is described as a wheeled motor vehicle used for transporting, which also carries its own engine. The word automobile originates from the ancient Greek word auotos meaning "self" and the Latin word mobilis meaning "movable." The countries known for making cars include Brazil, Britain, Canada, China, Germany, India, Italy, Japan, South Korea, Thailand, United States and Malaysia. In the past, while automobiles were perceived as luxuries, they are a necessity for many people today (Olsen and Cabadas, 2002; Beecroft, 2009).

In Malaysia, Proton was established in 1983 under the direction of the former Prime Minister Mahathir Mohammad (Banting, 2006; Sundaram, 1993). Consumers' purchase intentions for automobiles is of a great importance to Proton car manufacturer to understand consumers' different tastes and preferences. In addition, everyone has different uses for cars. Vehicles are purchased for home use, for transporting heavy materials, for racing, for luxury, for rental businesses and for easy personal transportation. The automobile industry in the world is growing, and it is important to examine the factors that influence consumers' purchase intention for automobiles with emphasis on Proton vehicles. Although there has been some work done on the automobile industry in Malaysia, it has been limited and it has not focused on the consumer purchase intentions. Findings from this study could provide more insight into consumers' purchase intentions and on the specific factors that may not have been considered, yet are critical to purchase intentions among consumers.

\section{LITERATURE REVIEW}

Consumers' purchase intentions: Dodds et al. (1991) describe consumers' purchase intentions as the possibility of a consumer's willingness to purchase a specific product (Hou, $\mathrm{Du}$, and $\mathrm{Li}, 2008$; $\mathrm{Zhu}, 2004$ ). When a consumer intends to purchase a product, they take specific interest in that product. What is it that drives an individual to take interest in a particular product to purchase, particularly Proton automobiles? Based on the review of related literature on purchase intentions and consumers behavior, country image, product knowledge, price, product quality, brand name and advertising, were identified (Blackwell, Miniard, and Engel, 2001). Consequently, the following hypotheses were developed based on the review (Quek and Eze, 2010; Lee, Eze, and Ndubisi, 2011; Hou, Du, and Li, 2008; Lin and Zhen, 2005; Dickson and Sawyer, 1990; Brown and Stayman, 1992; Eze, Yap, and Lee, 2010; Long and Chun, 2006): 
H1: Country of origin will positively affect consumers' purchase intentions for Proton automobiles.

H2: Product knowledge will have a positive influence on consumers' purchase intentions for Proton automobiles.

H3: Product quality will have a positive influence on consumers' purchase intention for Proton automobiles.

H4: Price will have a positive influence on consumers' purchase intentions for Proton automobiles.

H5: Brand image will have a positive influence on consumers' purchase intention for Proton automobiles.

H6: Advertising will have a positive influence on consumers' purchase intentions for Proton automobiles.

\section{RESEARCH METHOD}

Participants in this study were selected through a convenience sampling method. Four states in Malaysia were selected for this study, which were Malacca, Kuala Lumpur, Johor and Penang. These four states were chosen because they are located at key business operations, and for their significant economic contributions to Malaysia. The survey questionnaire was divided into two sections. The first section contained questions and statements on the respondents' background (age, gender, income level and ethnicity), while the second section contained questions/statements on the variables in the conceptual framework (Eze, 2008; Sekaran, 2003; Long and Chun, 2006). Each variable had about 3-8 items. A 5-point Likert scale was used to measure the items, where "1" = "Strongly Disagree" to " $5 "=$ "Strongly Agree." Content validity was conducted by five professionals ( 3 academics and 2 industry experts) to examine the relevance and coverage of construct items in the questionnaire. Their comments and advice were considered as we revised the questionnaire for final survey (Eze, 2008). We then conducted a pilot study with 100 participants to examine the face validity of the questionnaire (Sekaran, 2003). Some of the questions that appeared confusing or irrelevant were revised and the questionnaire was updated accordingly. In distributing the questionnaire, we used the personal administration method (Quek and Eze, 2010; Hou, Du, and Li, 2008; Eze, Yap, and Lee, 2010).

\section{DATA ANALYSIS AND FINDINGS}

One thousand and eighty copies of questionnaire were distributed for this study, and 1018 copies were returned. However, 30 questionnaires were invalid due to 
missing dates, which left us with 988 valid responses. The Statistical Package for Social Science (SPSS) was used to conduct the data analysis. The descriptive analysis reveals that most of the respondents were from Malacca with a percentage of 32. It shows also that males have a higher percentage of response at 62.1 percent compared to female respondents, 37.9 percent. The age range of respondents that dominated the study is 20-27 years with a percentage of 60.8 percent. The ethnic group with the most respondents is the Malay group (62.1\%). Most of the respondents (87.5\%) earn a salary range of RM1000 to RM4000. In addition, factor analysis was conducted to ensure that the items adequately represent the constructs that they were supposed to measure. The analysis revealed that the items for each construct converged into the specific construct they measured at a loading of 0.650 to 0.890 . Hence, all the items emerged relevant and statistically important as measures for the constructs.

On the mean analysis, product knowledge emerged with the highest mean value ( $\mathrm{PK}=3.98)$. Advertising yielded the lowest mean value ( $\mathrm{AD}=3.47)$. Generally, the nine variables' mean values are within the "tend to agree" range, indicating that the respondents, based on the data set, were more likely to agree with the statements on the variables, particularly as companies embark on initiatives to improve their business performance. The variables' $\alpha$ were above 0.60 , which indicated acceptable internal consistency; therefore, all variables could be used for further analysis. Product quality had the high reliability value at 0.881 ; followed by advertising $(0.820)$, product knowledge $(0.792)$, brand image $(0.778)$, price $(0.755)$, country of origin $(0.630)$, and consumer purchase decision (0.629).

The findings from the correlation matrix suggest that the variables are moderately correlated. This ensures that the data could be subjected to further analysis. The results also show that $\mathrm{R}=0.573$ and $\mathrm{R} 2$ value $=0.329$. This indicates that all the combined predictors can explain $32.9 \%$ of the variation in $\mathrm{Y}$ (the dependent variable). Additional testing indicates the F-value $=20.008$ with a $\mathrm{p}$-value $=0.000<0.05$. Hence, we can conclude that at least one of the six independent variables can be used to predict the research model. Table 1 reveals the multiple regression analysis. The results indicate that all the independent variables have positive effects on the dependent variable. Based on the p-value, the results indicate that, at significance level of 0.05 , four of the hypotheses are significant, as the p-values are lower than 0.05 . Hence, all the independent variables had significant influence on consumer purchase intention except brand image and product quality. This could be because of the high number of youth responses, who required vehicles mainly for functional needs. Hence, Advertising, Price, Product knowledge, Country of Origin have positive influence on purchase intentions. 
Table 1 Independent Variables and Consumers' Purchase Intention Regression Analysis

\begin{tabular}{|c|c|c|c|c|c|c|c|c|}
\hline \multicolumn{9}{|c|}{ Coefficients $^{\mathrm{a}}$} \\
\hline & \multirow{2}{*}{ Model } & \multicolumn{2}{|c|}{$\begin{array}{l}\text { Unstandardized } \\
\text { Coefficients }\end{array}$} & \multirow{2}{*}{$\begin{array}{c}\text { Standardized } \\
\text { Coefficients } \\
\text { Beta }\end{array}$} & \multirow{2}{*}{$\mathrm{t}$} & \multirow{2}{*}{ Sig. } & \multicolumn{2}{|c|}{$\begin{array}{c}\text { Collinearity } \\
\text { Statistics }\end{array}$} \\
\hline & & B & $\begin{array}{l}\text { Std. } \\
\text { Error }\end{array}$ & & & & Tolerance & VIF \\
\hline 1 & (Constant) & 1.024 & 0.264 & & 3.946 & 0.000 & 0.838 & 1.193 \\
\hline & Country of origin & 0.185 & 0.054 & 0.202 & 3.435 & 0.001 & 0.791 & 1.264 \\
\hline & Knowledge & 0.234 & 0.056 & 0.274 & 4.192 & 0.000 & 0.643 & 1.555 \\
\hline & Quality & 0.014 & 0.051 & 0.018 & 0.270 & 0.787 & 0.652 & 1.534 \\
\hline & Price & 0.190 & 0.053 & 0.102 & 2.678 & 0.000 & 0.740 & 1.352 \\
\hline & Image & 0.069 & 0.058 & 0.055 & 0.539 & 0.125 & 0.714 & 1.401 \\
\hline & Advertising & 0.136 & 0.045 & 0.173 & 3.022 & 0.003 & 0.838 & 1.193 \\
\hline
\end{tabular}

a. Predictors: (Constant), Country of origin, Price, Quality, Image, Knowledge, Advertising

b. Dependent Variable: Consumer purchase intention

\section{CONCLUSION}

Based on the findings, four factors appeared significant. Specifically, the findings indicate that vehicle's country of origin does matter to the participants. Therefore, if a country does not have a good reputation in manufacturing an automobile, the consumer would feel uncomfortable purchasing a car from such a country. Thus, Proton, in conjunction with relevant authorities in Malaysia, has to continue building its country's image to win consumers. Furthermore, the findings indicate that the participants would rather purchase a model of a Proton automobile for which they have more information. Zhu (Lin and Zhen, 2005) states that, in a RV leisure van research, when the consumers select a product, they usually rely on their product knowledge to evaluate it, and their product knowledge would affect their information search process, attitude, and information search quantity.

In addition, product quality influences purchase intention although the influence was not strong. This may be because those who tend to own proton cars may not be high-income earners. Most of the participants tend to be college students, whose key interest may not be quality, as they plan to purchase another car soon after graduation. However, it is important to note that product quality still does affect the consumer's purchase intentions. Price and advertising also have an effect on the consumers' purchase intention for Proton automobiles. Most college students are price sensitive, meaning the price does affect their decisions when purchasing cars. To college students, the image of Proton automobile matters a great deal as having a nice brand tends to give one a good status, socially. Although based on the findings from this 
study, brand image does not affect purchase intentions of consumers, which could be explained by the fact that consumers of Proton automobiles do not consider brand name a priority in their decisions.

In addition, advertising influences purchase intention since it is a means through which most of the buyers know about the Proton and other models in the market. Thus, it is important for Proton to focus on these factors when producing future automobiles. Proton could use these findings to assess its strategy with respect to the factors discussed in this paper. This could help to provide Proton with some perspectives on the market circumstances and probably help in designing effective marketing and business strategies to address specific consumers' requirements. These are very important for Proton to continue to gain and maintain competitive position in the marketplace. On a final note, future research may consider a comparative analysis among products from different manufacturers in the country and the region, say, Thailand, Indonesia, and South Korea, to gain a better perspective on consumers' purchase decision for an automobile. In addition, a comparison among different Proton automobiles would be very useful to the car markers.

\section{REFERENCES}

Banting, E. (2006). Inventing the automobile. New York: Crabtree.

Beecroft, D. (2009). History of the American automobile industry. Australia: Dorling Kindersley.

Blackwell, R. D., Miniard, P. W., and Engel, J. F. (2001). Consumer behaviour., Orlando, FL: The Dryden Press.

Brown, S. P. and Stayman, D. M. (1992). Antecedents and consequences of attitude toward the Ad: A meta-analysis. Journal of Consumer Research, 19(1), 34-51.

Dickson, P. R. and Sawyer, A. G. (1990). The price knowledge and search of supermarket shoppers. Journal of Marketing, 54(3), 42-53.

Dodds, B. K., Monroe, K. B., and Grewal, D. (1991). Effect of price, brands and store information on buyers' product evaluation. Journal of Marketing Research, 28(3), 307-319.

Eze, U. C. (2008). E-business deployment in Nigerian financial firms: An empirical analysis of key factors. International Journal of E-Business Research, 4(2), $29-47$. 
Eze, U. C., Yap, L. S. L., and Lee, C. H. (2010, December). The Relationship between Key Factors and Consumers' Attitude towards Advertising. Papers presented at the International Borneo Business Conference (IBBC2010), Sarawak, Malaysia. Abstract retrieved from http://www.feb.unimas.my/ibbc2010/

Hou, J., Du, L., and Li, J. (2008). Cause's attributes influencing consumer's purchasing intention: Empirical evidence from China. Asia Pacific Journal of Marketing and Logistics, 20(4), 363-380.

Lee, C. H., Eze, U. C., and Ndubisi, N. O. (2011). Analysing key determinants of online repurchase intentions. Asia Pacific Journal of Marketing and Logistics, 23(2), 200-221.

Lin, L. Y. and Zhen, J. H. (2005). Extrinsic product performance signaling, product knowledge and customer satisfaction: An integrated analysis - An example of notebook consumer behavior in Taipei City. Fu Jen Management Review, 12(1), 65-91.

Long, Y. L. and Chun, S. C. (2006). The influence of the country-of-origin image, product knowledge and product involvement on consumer purchase decisions: An empirical study of insurance and catering services in Taiwan. Journal of Consumer marketing, 23(5), 248-265.

Olsen, B. and Cabadas, J. P. (2002). The American auto factory (Automotive history and personalities). Canada: Motorbooks International.

Quek, A. S., and Eze, U. C. (2010, June). Evaluating product and service quality in Malaysia: Customers' perspective. Paper presented at the Technology Innovation and Industrial Management (TIIM2010), Pattaya, Thailand.

Sekaran, U. (2003). Research Methods for Business, A skill Building Approach (4th ed.). New York: Holt.

Sundaram, J. K. (1993). Malaysian industrialisation in historical perspective. London: Routledge.

Zhu, P. T. (2004). The relationship among community identification, community trust, and purchase behavior - The case of RVs communities. Unpublished Masters degree thesis, Graduate School of International Business, National Dong Hwa University, Shoufeng, Taiwan. 
